DOI: https://doi.org/10.34069/AI/2021.46.10.17

How to Cite:

Yermakov, Y., Shumeiko, D., Tarasenko, O., Voloshyna, M., \& Chyzh, S. (2021). Investigative activities of operational units in the detection of criminal offences in the sphere of subsoil exploitation and protection. Amazonia Investiga, 10(46), 176-183. https://doi.org/10.34069/AI/2021.46.10.17

\title{
Investigative activities of operational units in the detection of criminal offences in the sphere of subsoil exploitation and protection
}

\section{Пошукова діяльність оперативних підрозділів під час виявлення кримінальних правопорушень у сфері охорони та використання надр}

Received: September 15, 2021
Accepted: November 1, 2021

\begin{abstract}
The purpose of the article is to determine the features of the search for signs of criminal offenses in the sphere of subsoil exploitation and protection. The subject of the study is the search activities of operational units in this area. The research methodology includes the use of general scientific and special methods of scientific cognition: dialectical, historical-legal, formallogical, system-structural, generalization, comparative-legal. Research results. The elements of search activity of criminal offenses in the area of subsoil exploitation and protection are established. Practical meaning. The most likely places of search and objects containing information on wrongfulness of the acts in the indicated sphere are identified. Value / originality. It is proved that process of detecting criminal offenses and those who prepare or commit them is based on the knowledge of the event of criminal offense by subtraction from the environment the changes that have arisen in connection with its preparation or commission of
\end{abstract}

Анотація

Метою статті $\epsilon$ визначення особливостей пошукової діяльності ознак кримінальних правопорушень у сфері використання та охорони надр. Предметом дослідження $\epsilon$ пошукова діяльність оперативних підрозділів у сфері охорони та використання надр. Методологія дослідження включає в себе використання загальнонаукових та спеціальних методів наукового пізнання: діалектичний, історико-правовий, формально-логічний, системно-структурний, узагальнення, порівняльно-правовий. Результати дослідження. Встановлено елементи пошукової діяльності кримінальних правопорушень у сфері використання та охорони надр. Практичне значення. Виокремлено найбільш вірогідні місця пошуку та об'єкти, що містять відомості про протиправність діянь у сфері надрокористування. Цінність/оригінальність. Зазначено, що процес виявлення кримінальних правопорушень та осіб, які їх

\footnotetext{
${ }^{66}$ Candidate of Legal Sciences, Associate Professor (Kyiv, Ukraine).

${ }^{67}$ Doctor of Legal sciences, Associate Professor, Associate Professor of the Department of Criminal Procedure of the National Academy of Internal Affairs, Ukraine.

${ }^{68}$ Candidate of Legal Sciences, Associate Professor, Associate Professor of the Department of Operational and Search Activity of the National Academy of Internal Affairs (Kyiv, Ukraine).

${ }^{69}$ Candidate of Legal Sciences, Associate Professor of the Department of Operational and Search Activity of Dnipropetrovsk State University of Internal Affairs, Ukraine.

${ }^{70}$ Candidate of Legal Sciences, Senior Lecturer of the Department of Pre-investigative and Detective Activity of Kharkiv National University of Internal Affairs, Ukraine.
} 


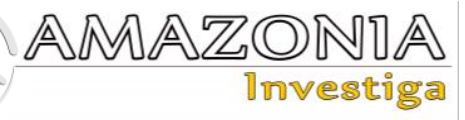

the traces left on the environmental elements, such as objects and documents.

Keywords: sphere of subsoil use and protection, criminal offenses, search activity, detection of signs, search elements.

готують або вчинили, заснований на пізнанні подіï кримінального правопорушення шляхом вичленення 3 навколишнього середовища змін, які виникли у зв'язку з його підготовкою або здійсненням по залишених слідах на елементах середовища, якими $€$ предмети та документи.

Ключові слова: сфера використання та охорони надр, кримінальні правопорушення, пошукова діяльність, виявлення ознак, елементи пошуку.

\section{Introduction}

The organized and latent nature of criminal offenses committed in the in the sphere of the conservation and use of mineral resources, their dissemination and inefficiency of the State system of combating illegal mineral resources use, as well as the need to supplement the State budget requires the use of force and resources of operational and investigative activities. The statistics of law enforcement agencies in this area are extremely low, although the subsoil use remains the object of encroachment by organized criminal groups. Such criminal offenses such as theft, smuggling, illegal economic activities, corruption offenses, etc. may be committed in the process of illegal mining. There is an increase in their level, the complexity of the structure, its encumbrance of organized forms of criminal activity, conflation of environmental, organized and political crime (Maksimentsev, 2019, p. 109). Criminal offenses in this area are among the most common, and their level is steadily increasing (compared to 2002, the annual number of reported offenses in this category has increased more than 10 times. Their share in the structure of environmental crime is currently $18.6 \%$, while in 2002 this figure was $4.3 \%$ ) (Turlova, 2018, p. 91, 98). But these are only official figures; the real state of affairs is much worse. Ukraine repeats and joins global trends; according to the Interpol report on the state of environmental crime over the past decade the growth of this type of crime was at least $5-7 \%$ per year (Interpol, 2016). The latent (hidden) nature of criminal activity in this area necessitates the active acquisition of primary operational information (Shapovalov, 2015, p. 184), and it is the activation of operational units, their search activities that will significantly reduce the latency of criminal offenses in the area of subsoil conservation and use.

The purpose of our article is to determine the features and highlight the main elements of the search activities of operational units in the

detection of criminal offenses in the sphere of the exploitation and protection of the subsoil.

\section{Methodology}

To achieve the goals and objectives of the scientific research, to ensure the reliability of the results and proper justification of the conclusions of the study, the authors used both philosophical, general scientific and special scientific methods of knowledge.

Thus, logical method is applied for the consideration of legal acts regulating the problem under consideration, the relevant statistical data, concepts, opinions of the authors on certain aspects of the subject matter of the research, as well as for the generalization and formulation of the conclusions.

Statistical method is helpful in analyzing statistical information of law enforcement agencies on the delinquency in the area of subsoil use.

System and structural method makes it possible to identify the locations to organize search activities in the area of subsoil exploitation use and protection, as well as to classify the objects of search activity in this sphere according to the relevant criteria.

Logical and legal method helps to formulate proposals for improving the legislation governing activities related to the detection and investigation of criminal offenses under consideration.

\section{Literature Review}

Over the last decade, criminal actors engaged in illegal mining have made huge amounts of illicit profits at the expense of countries' economies, 
vulnerable populations, and the environment (Interpol, 2021, p. 3).

The scholars who have studied the issue under consideration have expressed different views on the place of search activity in the general system of combating crime; its content and admissibility under conditions when a criminal offense has not yet been committed; differences from the activities related to the search for persons suspected of committing other criminal offenses, etc. For example, Shapovalov (2015), Nikolayuk (2009), Nekrasov, Borets, and Myronenko (2008) developed the basic conceptualcategorical apparatus of search activity, made a significant contribution to the study of problems of finding signs of criminal offenses. Some scholars examined the peculiarities of the search for criminal offenses (in scientific developments devoted to: combating the illicit trafficking of precious metals and stones (Kazantsev, 2006), public administration in the area of subsoil use (Surilova, 2014), counteraction to economic crimes in the coal industry (Tytarenko, 2008), illegal circulation of amber (Khmurovska, 2009), without distinguishing the elements of search activity due to the specific features of the exploitation and protection of the subsoil.

A number of foreign scholars devoted their works to some aspects of illegal mining in their regions. For example, Funoh (2014) investigated the impacts of artisanal gold mining on the environment of Cameroon, which are deforestation and land degradation, open pits which pose animal traps and health hazards, and mercury pollution, dust and noise pollution.

McNeish (2018) examined the problem of resource extraction in Latin America and came to the conclusion that despite the existence of laws that regulate the actions of the State and multinational corporations, governments obsessed with economic growth at any cost exploit legal loopholes, conventional science and the media to bend the rules and criminalize the opposition.

Tsabora (2014) dedicated his research to the problem of illicit natural resource exploitation in Africa's maritime zones. As the result he proposes a strategy for criminal sanctions against this conduct.

Salazar et al. (2021) provided an overview of mining in Columbia and covered some of the key legal issues commonly associated with the exploration and extraction of mineral resources in this country. These issues form part of any due diligence exercise conducted by an investor proposing to acquire mining assets or an interest in a mining project.

As one can see, the scholars, who have studied the issue under consideration, have expressed different views on the place of search activity in the general system of combating crime, its content and admissibility in circumstances when a criminal offense has not yet been committed; differences from the activities related to the search for persons suspected of committing criminal offenses, etc. However, they did not allocate the elements of search activity related to the specific features of the exploitation and protection of the subsoil.

\section{Results and Discussion}

There are two main directions of the exploitation of natural resources in Ukraine (including for filling of the budget): the first one is agricultural production, and the second one - mining and use of minerals. Accordingly, it is in these areas that criminal activity is most active and hidden. As for the need for active counteraction to these criminal manifestations by State institutions, it is dictated by both negative changes in the economic situation and the negative balance of the State budget of Ukraine. Predatory attitude to the subsoil leads to the formation of waste heaps, intense dust and air pollution, pollution of surface and groundwater, the development of subterranean spaces, terrestrial sedimentation, artificial decay, wetlands (Volkova, \& Volkova, 2005 , p. 134), the negative impact on the environment, as well as the exceedance of maximum allowable concentrations of many chemical elements on the soil (Volkova, 2006, p. 130). In this regard Suleimanov et al. (2020, p. 99) note that during, for example, the process of an oil field exploitation, a broad spectrum of pollutants including saturated and unsaturated aromatic hydrocarbons, hydrogen sulfide, oxides of carbon and nitrogen, phenol, formaldehyde, sulfurous anhydride, etc. that are present in the human environment in dangerous concentrations (above the maximum admissible concentration (MAC) is released to ambient air, topsoil and water bodies.

The high degree of criminalization of the subsoil exploitation is due to the active illegal mining by not only the local population, but also by the powerful conglomerate in the form of financial and industrial groups (based on mining, exploitation, sale and export of minerals). The core of criminal subsoil use is non-competitive, corrupt, large-scale extraction of the widest range 


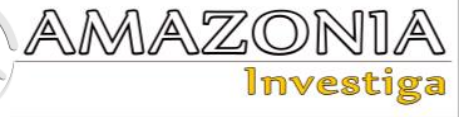

of extraction of various types of minerals. The representatives of organized criminal groups specializing in criminal practices in the area of subsoil exploitation (one of the most profitable in the State) are the members of central and local government, the municipality; they influence State policy, both sectoral and national, which causes problems at the stage of obtaining primary information about these criminal offenses (Maksimentsev, 2019, pp. 74 - 75).

Participation in counteracting operational units is due to the high latency of criminal offenses in this area. Analyzing the factors of latency and taking into account the possible indicators of the distribution of latent criminal offenses by the sources of latency, we identify:

undeclared latent crime $(72.7 \%$ ) (due to the lack of statements and reports of illegal mining); hidden latent crime (52.2\%) (due to concealment of the fact or illegality of mining); undetected latent crime (32\%) due to passive actions of regulatory and law enforcement agencies for various reasons.

The search for factual data on the facts of criminal offenses in the sphere of subsoil exploitation and protection is carried out in the following forms: search for primary information on indications of as yet unknown illegal activity; search for additional information on the signs of already known criminal offenses related to illegal mining.

Detection of the facts of criminal offenses and persons who committed them is carried out at the following levels: search for indications of certain forms of violation of the mining practices $(29.5 \%)$; search for signs of criminal activity, which covers the entire cycle of subsoil use (from illegal mining of minerals to export operations involving extracted materials) (41.8\%); search for persons who organize criminal offenses in the area of subsoil exploitation and protection $(28.3 \%)$.

Specific search areas are identified for each of the types of criminal offenses in a particular sector of the economy. We distinguish the following locations to organize search activities in the area of subsoil exploitation use and protection:

- general search areas (State bodies that permit mining and mineral extraction and, accordingly, control the subsoil use (information from them is noted in $76.3 \%$ of the studied materials); State bodies that have competence to protect the environment and other public relations that may be harmed as a result of illegal subsoil development $(50.4 \%)$, public environmental associations $(14.8 \%)$;

- places where publicly available information on the consequences of committing criminal offenses in the field of subsoil use and protection is concentrated $(23.4 \%$ ) (Internet resources of general purpose (social networks; specialized purposes));

- search areas that are directly related to the technological stages of the subsoil use process (their definition depends on the characteristics of subsoil mining, based on the need for strategic deployment of operational units): in certain territories that formally condition the location of the search (location of mineral deposits); search places are created according to certain aspects of the legal status of the land plot and mineral deposits located on it (ownership and land use regime; differentiated approach of the legislator to the legal assessment of illegal mining of national importance and illegal mining of local importance; method of possible future production and the resources required for this; previous mining: the places where the capacity of economic entities which are authorized to use subsoil are located $(28.3 \%)$;

- mining sites used by citizens within the limits of the allotments granted to them $(8.6 \%)$; man-made mineral deposits $(11.1 \%)$;

- refineries engaged in processing of extracted minerals $(8.6 \%)$; other mineral processing facilities $(6.2 \%)$;

- places where previously abandoned mines, deposits, quarries, etc. were located $(52.9 \%)$; places where illegal extraction of minerals is carried out $(52.9 \%)$;

- places where mining is prohibited due to the risk of destruction or contamination $(20.9 \%)$; sites containing the effects of illegal mining (19.7\%);

- excavation sites under the guise of illegal mining (13.5\%); location (or routes) of transportation of illegally extracted minerals $(6.2 \%)$;

- places where special technical equipment for mining of minerals can be manufactured or repaired $(8.6 \%)$.

The objects of search activity are persons of operational interest, items and documents.

The persons who are of operative interest are classified by the authors according to the following criteria: 
- functional criterion (in terms of participation (possibility) in criminal offences):

* the first level: the persons who have an opportunity to commit criminal offenses in the area of subsoil use due to their professional functions, i.e. who are potential criminals due to certain skills and abilities (or awareness of certain facts), or certain actions (at the time of the search);

* the second level: the persons who, due to legal restrictions, can be classified as objects of search;

* the third level: the persons who have an opportunity to commit criminal offenses in the area of subsoil exploitation and protection, as well as appropriate sociocriminological personal characteristics;

* the fourth level: the persons who illegally mine minerals without understanding the illegality of their actions;

* the fifth level: the persons who have an opportunity to commit criminal offenses, relevant characteristics and incidental data indicating their affiliation to criminal activity;

- subjective criterion (depending on the position (on which object the mine is performing, mining control, permitting mining activities, protection of subsoil or environment) and / or the role during preparation for commission of criminal offenses in the area of subsoil exploitation and protection: officials who have a special legal status in the area of subsoil extraction and protection; officials whose functions include control over the exploitation and protection of subsoil (there are two types of these persons : those who provide illegal mining (permitting bodies in the area of exploitation and protection of subsoil) and those who should prevent illegal extraction of minerals and ensure the protection of the environment); persons holding "criminogenic" positions at enterprises (of various forms of ownership operating in the area of mining and protection of subsoil); persons who obtained appropriate geological and mining education and carry out exploration of mineral resources; persons who directly carry out the extraction of minerals; persons who are the heads of economic entities authorized to extract minerals;

- target criterion (in terms of efficiency of the use in the search process:

* the persons who are not directly involved in the illegal exploitation of minerals, but contribute to their further implementation;
* the persons who may have information on the commission of a criminal offense and / or persons who received information as a result of the performance of their official duties. These persons are of different levels of operational and investigative interest: persons who received information as a result of the performance of their official duties; persons who perform their duties or live off forests and land use; technical staff of subsoil use entities; persons who participate in illegal activities, but perform secondary functions (and may be unaware of the illegality of their actions).

The objects of search activity are the items of physical world, which are classified according to their significance for operational units at each stage of illegal activity: objects that do not contain signs of a crime, but their location in a certain place (or in the possession of a certain person) may indicate the preparation or commission of a criminal offense, i.e. the presence of these items in the mining place allows to consider them as the object of search activity, and their location elsewhere under other circumstances is not a search feature of a criminal offense.

The objects of search are: minerals (precious) semi-precious organogenic stones $(2.5 \%)$, coal $(17.2 \%)$, ground fresh water $(8.6 \%)$, sand-gravel mixture $(14.8 \%)$ ), molding sand $(7.4 \%)$, tuff $(6.2 \%)$, sandstone $(4.9 \%)$, mineral water $(2.5 \%)$, clay-stone mixture $(22.1 \%)$, granite $(9.8 \%)$, iron and quartzite-magnetite ore $(1.2 \%)$, precious metals $(2.5 \%)$ ); means of committing illegal mining (23.4\%); technical means of changing the parameters of the technological process $(8.6 \%)$, which are used for measurement at different technological stages and may contain constructive changes made by criminals; computer and printing equipment used by criminals to commit a criminal offense $(3.7 \%)$, including forgery; funds $(38.1 \%)$ : in cash; in non-cash form; other items that are not carriers of handwritten and printed information, but contain material traces of criminal acts $(3.7 \%)$ (items related to the work of the offender (seals, stamps, forms, servers, drives, etc.).

Documents certifying criminal activity as an object of search activity are divided by functional categories: registration; title; authorization; environmental protection documents (regulating environmental protection); organizational and economic documents; financial and accounting documents; technological documents; transport documents; documents of all categories used in 


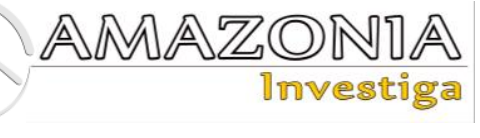

the area of subsoil exploitation and protection, which have signs of partial or complete forgery (technically or intellectually).

The search features of preparation and commission of criminal offenses in the area of subsoil exploitation and protection are: technological features (changes in the processes of preparation for mining and actual mining of minerals) (64.4\%); subjective characteristics of persons as the objects of search (specific skills, abilities and experience of both legal and illegal activities in the area of subsoil exploitation and protection); behavioral characteristics of the person (65.2\%); legal features (indirect and direct features that indicate violation of the requirements of regulations governing the use and protection of subsoil) (12.6\%); objective signs (indicating specific facts) (40.3\%); documentary features $(37.4 \%)$; organizational features: signs that indicate changes in certain organizational procedures, processes (9\%); economic signs (13\%). Criminological signs indicate the reasons that determine the possibility of committing criminal offenses in the area of subsoil exploitation and protection, as well as the conditions that contribute to their commission.

We identify the following most effective, in our view, tools of search activity in the process of detection of criminal offenses in the area of subsoil exploitation and protection:

Information and analytical prediction (the content of which is to obtain information from open sources and its analytical processing from the following perspectives: comparison of information received with information already known in the public domain; equalization of public information with that received from hidden sources; forecasting the development of the operational situation taking into account these data, implemented through the use of methods:

- method of economic and legal analysis $(10.4 \%)$ of the activities of legal enterprises in the area of subsoil exploitation and protection;

- method of operational and economic analysis $(9.4 \%)$, which includes analysis of the existing information on the criminogenic situation in relation to the trends in criminal offenses in the area of subsoil exploitation and protection on the basis of events that have occurred and the impact on the development of such a situation (for example, increasing demand for specific minerals);operational and analytical method

$(36.7 \%)$ is based on the study of operational materials regarding the operational and tactical situation that has developed as a result of criminal actions in the area of subsoil exploitation and protection and forecasting its further development;

- analytical and software method (5\%) is based on the use of open databases as sources and their comparison with the data they contain.

\section{Conclusion}

Thus, the search activity in relation to criminal offenses in the area of subsoil exploitation and protection is a set of operational and intelligence activities carried out by operational units, aimed at actively obtaining, verifying, systematizing and using information on the signs of criminal offenses and the persons involved. The subject of knowledge (operative officer) should be familiar with the peculiarities of the object of exploitation and protection of subsoil, the technology of certain economic operations, as specific features of the process of establishing places and objects of search make it necessary to define deviations from the norm in the form of indicators arising in the material sphere (in certain places or at certain objects) as a result of illegal mining activities. Therefore, based on the peculiarities of the normal functioning of the object of exploitation and protection of subsoil and the implementation of subsoil use in a certain form, one can identify the most likely places of search, objects that bear traces of material and intellectual nature, containing information on the unlawfulness (criminality) of the act.

We identify the following elements of search activity of criminal offenses in the area of exploitation and protection of subsoil:

- places of search activity depend on the stage of committing criminal offenses and the functional content of possible criminal acts (general places of search; places where publicly available information on the consequences of committing criminal offenses in the area of subsoil exploitation and protection is concentrated; places of search directly related to technological stages of subsoil use process (their definition depends on the characteristics of subsoil extraction, based on the strategic deployment of operational units);

- the persons who are objects of search activities are classified depending on the level of functionality in terms of participation (opportunities) in the 
commission of criminal offenses: subjective depending on the position (depending on the position (on which object the mine is performing, mining control, permitting mining activities, protection of subsoil or environment) and / or the role during preparation for commission of criminal offenses in the area of subsoil exploitation and protection; targeted (in terms of efficiency of the use in the search process

- the objects of the physical world as the objects of search activity are classified as: instruments used in the commission of criminal offences, which in itself is a sign of their committing, which are defined as the objects of search activity only in the presence of certain circumstances (or signs) that indicate the possibility of their use for criminal purposes; i.e., certain items are available in a certain place or a person in combination with other operational information.

- the documents as the objects of search activity are classified depending on the stages of criminal activity, because at one stage these documents are considered as the objects of search activity that are important for operational units, but they are not so important at the others;

- search signs that indicate the commission of criminal offenses in the area of subsoil exploitation and protection (technological; legal; environmental; organizational and criminological features) depend on the stage of illegal activity (preparation for illegal mining or directly at the stage of mining).

The process of detecting criminal offenses and those who prepare or commit them is based on the knowledge of the event of criminal offense by subtraction from the environment the changes that have arisen in connection with its preparation or commission of the traces left on the environmental elements, such as objects and documents.

\section{Bibliographic References}

Funoh, K. (2014). The impacts of artisanal gold mining on local livelihoods and the environment in the forested areas of Cameroon. Working Paper 150. Bogor, Indonesia: CIFOR.

Interpol (2016). UNEP-INTERPOL report: value of environmental crime up $26 \%$. https://www.interpol.int/News-andEvents/News/2016/UNEP-INTERPOLreport-value-of-environmental-crime-up-26
Interpol (2021). Illegal gold mining in Central Africa: Analytical Report. https://webcache.googleusercontent.com/sea rch?q=cache:MBSuNqkSqRYJ:

https://www.interpol.int/content/download/1 6493/file/2021\%252007\%252027\%2520EN GLISH\%2520PUBLIC\%2520VERSION_FI NAL_Illegal\%2520gold\%2520mining\%252 0in\%2520Central\%2520Africa.pdf $+\& c d=14$ $\& \mathrm{hl}=\mathrm{ru} \& \mathrm{ct}=\mathrm{clnk} \& \mathrm{gl}=\mathrm{ua}$

Kazantsev, Yu. (2006). Methods of detecting crimes related to illicit trafficking of precious metals. In the collection: Problems of improving the efficiency of public administration in law enforcement of the scientific and theoretical conference. Kyiv: Academy of Management.

Kharytonov, E., Kharytonova, O., Kharytonova, T., Kolodin, D., \& Tolmachevska, Y. (2019). Human rights as the basic value of the concept of private law in modern Europe. Amazonia Investiga, 8(20), 477-485. Retrieved from https://amazoniainvestiga.info/index.php/am azonia/article/view/177

Khmurovska, L. (2009). Legal liability for illegal actions in relation to minerals of national importance. Scientific Bulletin of Kyiv National University of Internal Affairs, No. 5, pp. 154-165.

Maksimentsev, M. (2019). Criminological principles of counteraction to crime in the sphere of subsoil use. (PhD Dissertation). Kharkiv National University of Internal Affairs, Ukraine.

McNeish, J. (2018). Resource Extraction and Conflict in Latin America. Colombia Internacional, No. 93, pp. 3-16. https://www.redalyc.org/journal/812/812568 49001/html/

Nekrasov, V., Borets, L., and Myronenko, S. (2008). Detection of legalization (laundering) of proceeds from crime (operational and investigative aspect): practical guide. Kyiv: Publishing House "Skif", KNT.

Salazar, D., Serrano, E. and Ochoa, A. (2021). Mining in Columbia: Overview. Thomson Reuters Practical Law. https://uk.practicallaw.thomsonreuters.com/ w-019-

7418?transitionType $=$ Default $\&$ contextData $=$ (sc.Default)\&firstPage $=$ true

Shapovalov, O. (2015). Operational search for signs of latent crimes in the sphere of economic activity. Prykarpattya Legal Bulletin, No. 3 (9), pp.183-187.

Suleimanov, R., Bakirov, A., Gimranova, G., \& Valeev, T. (2020). Hygienic assessment of health risks of the population living in the 


\section{AMAZONIA \\ 1กvestiga}

areas of intensive oil extraction. Amazonia Investiga, 9(26),

97-104.

https://doi.org/10.34069/AI/2020.26.02.11

https://amazoniainvestiga.info/index.php/am azonia/article/view/1121/1022

Surilova, O. (2014). State management of the use and protection of subsoil of Ukraine: monograph. Odessa: Galician Publishing Union LLC.

Tarasenko, O., \& Nikolayuk, M. (2009). Detection of land-related crimes. In the collection: Current state and prospects of development of operational and search activity under European integration of the round table. Kirovoghad: Kirovohrad Law Institute of Kharkiv National University of Internal Affairs. http://elar.naiau.kiev.ua/bitstream/12345678 9/18609/1/15.0.pdf

Tsabora, J. (2014). Illicit Natural Resource Exploitation by Private Corporate Interests in Africa's Maritime Zones During Armed Conflict. Natural Resources Journal, 54(1), pp. $181-204$.

Turlova, Iu. (2018). Combating Environmental Crime in Ukraine: Criminological and
Criminal Legal Fundamentals. Institute of State and Law. V.M. Koretsky National Academy of Sciences of Ukraine. http://idpnan.org.ua/files/2018/turlova-yu.a.protidiya-ekologichniy-zlochinnosti-vukrayini-_kriminologichni-ta-kriminalnopravovi-zasadi_-_d_.pdf

Tytarenko, O. (2008). Criminological characteristics and counteraction to economic crimes in the coal industry: monograph. Dnipropetrovsk: Dnipropetrovsk State University of Internal Affairs.

Volkova, K. and Volkova, T. (2005). Ecological danger of the coal industry. Environmental protection and rational use of natural resources: Collection of Donetsk National Technological University, Vol. 2, pp. 134- 135

Volkova, T. (2006). Ecological problems of the Donetsk region in the legal framework of Ukrainian legislation. Scientific works of Donetsk National Technological University. Series: Mining and Geological, 2(111), pp. 128-136. http://masters.donntu.org/2012/feht/snezhok/ library/article4.htm 